\title{
CORRIGENDUM
}

\section{The pan phosphoinositide 3-kinase/mammalian target of rapamycin inhibitor SAR245409 (voxtalisib/XL765) blocks survival, adhesion and proliferation of primary chronic lymphocytic leukemia cells}

R Thijssen, J ter Burg, GGW van Bochove, MFM de Rooij, A Kuil, MH Jansen, TW Kuijpers, JW Baars, A Virone-Oddos, M Spaargaren, C Egile, MHJ van Oers, E Eldering, MJ Kersten and AP Kater

Leukemia (2016) 30, 1963; doi:10.1038/leu.2016.184

Correction to: Leukemia (2016) 30, 337-345; doi:10.1038/ leu.2015.241; published 10 November 2015

Following the publication of this article, the authors noted that the following Conflict of Interest statement was missing: EE, MJK and
APK have a sponsored research agreement with Sanofi. AVO and $\mathrm{CE}$ are employees of Sanofi. All other authors declare no conflict of interest. 